\title{
Collaborative Video Consultations from Tertiary Care Based Telepsychiatrist to a Remote Primary Care Doctor to Manage Opioid Substitution Therapy Clinic
}

\author{
${ }^{1}$ Department of Psychiatry, Tele Medicine Centre, National Institute \\ of Mental Health and Neurosciences, Bengaluru, India \\ ${ }^{2}$ District Hospital, Haridwar, Uttarakhand, India \\ ${ }^{3}$ Non Communicable Disease Cell, National Health Mission, \\ Uttarakhand, India \\ ${ }^{4}$ Department of Psychiatry, National Drug Dependence \\ Treatment Centre, All India Institute of Medical Sciences, \\ New Delhi, India
}

Erika Pahuja ${ }^{1}$ Santosh Kumar ${ }^{1}$ Ajay Kumar ${ }^{2}$ Fareed Uzzafar ${ }^{3}$ Siddharth Sarkar ${ }^{4}$ Narayana Manjunatha ${ }^{1}$ Yatan Pal Singh Balhara ${ }^{4}$ C Naveen Kumar ${ }^{1}$ Suresh Bada Math ${ }^{1}$

J Neurosci Rural Pract:2020;11:498-501

\author{
Address for correspondence Narayana Manjunatha, DPM, MD, \\ Department of Psychiatry, Tele Medicine Centre, National Institute of \\ Mental Health and Neurosciences, Bengaluru 560029, India \\ (e-mail: manjunatha.adc@gmail.com).
}

\begin{abstract}
Keywords

- primary care physician

- buprenorphine

- opioid

- opioid substitution therapy clinic

- OST

- Telepsychiatry

Opioid use is a major problem in India and has high morbidity and mortality with a prevalence of $2.06 \%$. There is a huge treatment gap for opioid use disorders (OUDs). Due to limited mental health resources and limited psychiatric training of medical practitioners in OUDs, a significant proportion of patients do not receive appropriate medical intervention. This article demonstrates how a primary care doctor working in a remote opioid substitution therapy (OST) clinic received assistance from the optional opioid module of clinical schedule for primary care psychiatry (CSP) and collaborative video consultation (CVC) module to address specific difficulties of patients already on Buprenorphine OST and improve the quality of care, thereby reducing chances of relapses. CVC module is a part of one-year digitally driven primary care psychiatry program designed by National Institute of Mental Health and Neurosciences (NIMHANS), Bengaluru. The opioid module was designed by NIMHANS, Bengaluru in collaboration with the All India Institute of Medical Sciences (AlIMS), New Delhi These observations warrant replication of this approach across diverse settings and at a larger scale to explore and evaluate its impact and effectiveness.
\end{abstract}

\section{Introduction}

Opioid use and dependence is a major problem in India and ranks first in disability-adjusted life-years lost and drug-related deaths. ${ }^{1,2}$ With limited mental health resources in India, primary care doctors (PCDs) are the first point of contact. Integration of psychiatric care into primary care may strengthen the health system and improve access to addiction services. Even though it is a pragmatic approach, it is associated with challenges like lack of psychiatric and addiction training during undergraduate training, which require attention.
Tele Medicine Centre, Department of Psychiatry, National Institute of Mental Health and Neurosciences (NIMHANS), Bengaluru, designed the primary care psychiatry program (PCPP) which is a one-year, part-time, modular-based, digitally driven, distance education-based clinical course called "Diploma in Primary Care Psychiatry" (DPCP) for in-service PCDs, especially from resource-poor states of India ${ }^{3}$ Along with mandatory modules in DPCP, there is provision of optional module, as per need of PCDs. The aim of PCPP is to integrate basic psychiatric care into primary care by mentoring PCDs at their workplace from an academic hospital. PCDs 
were trained using an all-in-one adopted training tool known as clinical schedule for primary care psychiatry (CSP) ${ }^{4,5}$ It contains rapid screener, taxonomy, diagnosis, treatment, and follow-up guidelines for six highly prevalent psychiatric disorders at primary care, namely, tobacco use disorder, alcohol use disorder, psychosis, somatization disorder, anxiety disorder and depression (abbreviated as TAP SAD). ${ }^{4,5}$ YPSB and NM designed an optional opioid module of CSP at request of AK who is PCD in-charge of opioid substitution therapy (OST). This paper intends to highlight the effectiveness of an optional opioid training module for a PCD.

\section{Methods and Results}

A batch of PCDs from Uttarakhand state, India, where lack of mental health professionals is alarming, was deputed by the National Health Mission for DPCP. One of the co-authors, A.K., is a PCD with MBBS degree, serving the Uttarakhand state since 2012. In 2017, he was posted in a district hospital and made in-charge of an already running OST clinic with 250 registered patients at that time. He did not have any prior formal training in managing patients with opioid use disorders (OUDs). He tried his best to manage OUD patients with help from his colleague managing another OST clinic at another district of Uttarakhand, reading study materials, observing the already employed workers in his OST clinic, and studying ongoing prescriptions of old patients. He frequently faced difficulty in managing certain patients but did not have any resource to guide him and always felt the need to have a formal training and structured module for the same. During his initial $2 \frac{1}{2}$ years, patient cohort increased up to 400 from 150 to 170 patients. As many as 10 to 15 patients per day required repeat consultation either for residual withdrawal symptoms, other substance use or general complaints.

As a part of his DPCP course in collaboration with telepsychiatrists of National Drug Dependence Treatment Centre (NDDTC), All India Institute of Medical Sciences (AIIMS), New Delhi using multipoint videoconference technology, A.K. underwent training using the collaborative video consultation (CVC) module of PCPP which is an on-demand, video streaming of live consultations. A.K. was sensitized in using the optional opioid module of CSP before CVC. During CVCs (two sessions over a week), AK was trained in handling management difficulties of his 11 patients afflicted with OUDs. The aim of this article is to provide details of how a digitally driven optional opioid module of PCPP helped a remotely practicing PCD in managing difficult patients of OST clinic, with focus on one/two learning points from each patient. The ethical committee of NIMHANS approved for file review of these patients.

Clinical difficulties faced by PCD in these 11 patients and learning points from the CVC in each patient are provided in - Table 1.

All 11 patients were males with a mean age of 30.64 (8.0) years and mean duration of illness 8.09 (2.74) years. Five (45.45\%) patients were intravenous drug users. None of them had any past history of other psychiatric illness. Two of them (18.2\%) were persons living with HIV and
AIDS (PLHAs). Four (36.4\%) patients had reduced sleep and four (36.4\%) had reduced appetite, whereas others had normal biological functions. Three (27.4\%) patients had reduced interest in work, causing occupational dysfunction. PCD identified seven patients (63.6\%) as opioid-dependent, and four (36.4\%) as polysubstance-dependent. The telepsychiatrist concurred all diagnoses made by PCD. Ten patients (90.9\%) were continued on buprenorphine with dose adjustments, whereas one patient (9.1\%) was managed with clonazepam for reduced sleep. Eight (72.7\%) patients did not require any other medicine, while one (9.1\%) required bupropion for comorbid active nicotine use. One patient was restarted on antiretroviral therapy (ART) and in one patient possibility of organicity for low back ache was considered. Using this module, PCD was able to manage all the patients at primary care level with assistance from a telepsychiatrist, and none of them required referral.

\section{Discussion}

In most parts of the country, PCDs are in the front line for patients with opioid addiction. Even though coverage of OST for OUDs is increasing in India, PCDs are not equipped to provide adequate treatment. In this paper, authors demonstrated the effectiveness of digitally driven CVCs between a telepsychiatrist and remotely practicing untrained PCD in an OST clinic for 11 difficult OUD patients. With this kind of telemedicine-based guidance from a telepsychiatrist, PCDs can be trained to manage OST clinic in remote PHCs, especially in the areas with high-prevalence of OUDs. In a large study on how PCDs address substance use disorders, less than 20\% described themselves as very prepared to identify alcoholism or illegal drug use, and more than $50 \%$ of patients with substance use disorders said their PCDs did nothing to address their substance abuse. ${ }^{6}$ This hampers retention of patients in the program and increases chances of relapse. There is reasonable evidence suggesting that primary care could be a preferred setting to manage OUDs. Randomized controlled trials conducted to compare management of OUDs in primary care versus specialty care reported higher patient satisfaction, retention, and street opioid abstinence in primary care. ${ }^{7,8}$ In India, wherein it is very difficult for PCDs to provide collaborative care for OUDs, OST is a boon, as there is evidence that it alone improves outcome, especially retention in the program. ${ }^{7}$ It is important to note that a PCD who was not trained in managing OUDs was able to engage and retain an increasing number of patients in a treatment loop during the initial 2 years. This denotes that if PCDs are properly trained and guided when required using video technology, they may act as a long-term viable solution to reduce treatment gap, morbidity, and mortality associated with OUDs. This paper describes how a digitally driven technology-oriented model can guide and empower PCDs to manage difficult OUD patients. It is important to understand the specific need of PCDs who are managing OST clinics, ensure PCD and patient satisfaction, and provide them a feeling of support. 
Table 1 Details of collaborative video consultations of 11 patients of opioid use disorders between telepsychiatrist and primary care doctor

\begin{tabular}{|c|c|c|c|}
\hline $\begin{array}{l}\text { S. } \\
\text { no }\end{array}$ & Case details & $\begin{array}{l}\text { Difficulty faced by } \\
\text { primary care doctor }\end{array}$ & Learning points \\
\hline 1. & $\begin{array}{l}\text { 30-year-old male with } 3 \text { years history of intravenous } \\
\text { opioid use (heroin), dextropropoxyphene cap- } \\
\text { sules, diazepam, nicotine ( } 20 \text { beedis/day); currently } \\
\text { abstinent and on BPN } 6 \text { mg (started with } 12 \mathrm{mg} \text { ), } \\
\text { with complaints of abdominal pain. Patient could } \\
\text { not take BPN one day as he had to travel. }\end{array}$ & $\begin{array}{l}\text { How to manage with- } \\
\text { drawal symptoms during } \\
\text { travel as extra dose of } \\
\text { medications cannot be } \\
\text { given. }\end{array}$ & $\begin{array}{l}\text { Explained need for medications for longer } \\
\text { time. } \\
\text { Options of tramadol regimen given as an } \\
\text { alternative to OST if patient has to travel } \\
\text { frequently or referred to nearby OST center. }\end{array}$ \\
\hline 2. & $\begin{array}{l}\text { 20-year-old male with } 1.5 \text { years history of use of } \\
\text { smack (heroin), currently abstinent on sublingual } \\
\text { BPN } 4 \text { mg/day with occasional craving. }\end{array}$ & $\begin{array}{l}\text { How to manage craving } \\
\text { despite on maintenance of } \\
\text { BPN } 4 \text { mg? }\end{array}$ & $\begin{array}{l}\text { Some patients may need higher BPN mainte- } \\
\text { nance dose due to craving. } \\
\text { Manage first with cue-induced behavioral } \\
\text { management. Then, increase dose of BPN } \\
\text { above } 4 \text { mg till craving subsides. }\end{array}$ \\
\hline 3. & $\begin{array}{l}\text { 26-years-old male, with } 3 \text { years smack (heroin) use, } \\
\text { abstinent from opioid for last } 8 \text { months, not on OST } \\
\text { for last } 3 \text { months, only complaint of reduced sleep }\end{array}$ & $\begin{array}{l}\text { How to manage sleep } \\
\text { problem in opioid absti- } \\
\text { nence patient when he is } \\
\text { not on OST? }\end{array}$ & $\begin{array}{l}\text { No need to restart BPN in absence of } \\
\text { opioid craving, benzodiazepines (preferably } \\
\text { long-acting) may be tried in managing sleep } \\
\text { with a strict vigil on BZD addiction. }\end{array}$ \\
\hline 4. & $\begin{array}{l}\text { 30-year-old male, with history of intravenous opioid } \\
\text { use for } 3 \text { years and is HIV positive, currently abstinent. } \\
\text { On regular OST and ART for } 4 \text { years. No complaints. } \\
\text { Currently, on BPN } 4 \text { mg (started at } 12 \text { mg). }\end{array}$ & $\begin{array}{l}\text { How long to give BPN } \\
\text { maintenance in this } \\
\text { patient? }\end{array}$ & $\begin{array}{l}\text { BPN maintenance for an extended period } \\
\text { (with periodic review). } \\
\text { Time being advised to continue same } \\
\text { treatment. } \\
\text { Trial of tapering after } 5 \text { years of maintenance. } \\
\text { Importance of regular brief counselling to } \\
\text { prevent relapse explained. }\end{array}$ \\
\hline 5. & $\begin{array}{l}\text { 26-years-old male, with history of injectable opioid } \\
\text { use, abstinent since } 2 \text { months. Active daily use of } \\
\text { nicotine and on and off use of alcohol. Currently, } \\
\text { on } 10 \text { mg of BPN. }\end{array}$ & $\begin{array}{l}\text { BPN dose is at higher } \\
\text { side. Can dose of BPN be } \\
\text { reduced in this patient? } \\
\text { How to manage nicotine } \\
\text { and alcohol in this } \\
\text { patient? }\end{array}$ & $\begin{array}{l}\text { Some patients need higher BPN dose. } \\
\text { Continue BPN in same dose in this patient. } \\
\text { Counselling and bupropion for nicotine. } \\
\text { Counselling for reducing alcohol use. }\end{array}$ \\
\hline 6. & $\begin{array}{l}21 \text {-year-old male, with history of } 2 \text { years opioid } \\
\text { use, currently abstinent, on BPN } 4 \text { mg/day since } \\
1 \text { month. Complaint of palpitations and body ache } \\
\text { daily evening }\end{array}$ & $\begin{array}{l}\text { How to manage evening } \\
\text { onset palpitations and } \\
\text { body ache in this patient } \\
\text { despite on BPN } 4 \text { mg? }\end{array}$ & $\begin{array}{l}\text { Consider palpitation and body ache as residual } \\
\text { opioid withdrawal symptoms. } \\
\text { Increase dose of BPN to eliminate this residual } \\
\text { withdrawal symptoms. }\end{array}$ \\
\hline 7. & $\begin{array}{l}25 \text {-year-old male with history of } 1 \text { year of opioids } \\
\text { use, } 10 \text { years of cannabis use, and } 1 \text { year alcohol } \\
\text { use. Currently, on } 4 \text { mg BPN. Off medications for } \\
4 \text { days. Complains of reduced appetite and reduced } \\
\text { interest in work. }\end{array}$ & $\begin{array}{l}\text { How to manage these } \\
\text { symptoms when patient } \\
\text { come after stopping BPN } \\
\text { for } 4 \text { days? }\end{array}$ & $\begin{array}{l}\text { Consider these as withdrawal symptoms } \\
\text { which may lead to lapses/relapses. } \\
\text { Encouraged restarting BPN } 4 \text { mg and } \\
\text { counselled the importance of BPN adherence }\end{array}$ \\
\hline 8. & $\begin{array}{l}\text { 28-year-old male with } 10 \text {-year history of use of } \\
\text { smack (heroin) and nicotine. Currently abstinent. } \\
\text { Complaints of occasional sleep disturbances. } \\
\text { Currently on BPN } 6 \text { mg. }\end{array}$ & $\begin{array}{l}\text { How to manage isolated } \\
\text { sleep problem in opioid } \\
\text { abstinence patient when } \\
\text { he is on BPN? }\end{array}$ & $\begin{array}{l}\text { As no other withdrawal symptoms apart from } \\
\text { sleep disturbances, no need to increase BPN. } \\
\text { Can try with short course of long acting BZD } \\
\text { for sleep and sleep hygiene }\end{array}$ \\
\hline 9. & $\begin{array}{l}\text { 42-year-old male with } 2-3 \text { years history of intrave- } \\
\text { nous opioid use as well as comorbid use of alcohol } \\
\text { and tobacco. Patient is also HIV positive. Difficulty in } \\
\text { managing patient on starting dose of } 0.8 \mathrm{mg} / \text { day. } \\
\text { Complaint of occasional withdrawal symptoms. }\end{array}$ & $\begin{array}{l}\text { How to manage occa- } \\
\text { sional withdrawal } \\
\text { symptoms in initial phase } \\
\text { while initiating low-dose } \\
\text { of BPN? }\end{array}$ & $\begin{array}{l}\text { Some patients need higher dose. Encourage } \\
\text { to try and stabilize on higher doses. }\end{array}$ \\
\hline 10. & $\begin{array}{l}\text { 45-year-old male with history of use of intravenous } \\
\text { opioid, cannabis and diazepam. Also, diagnosed } \\
\text { as HIV positive and a case of MDR TB. On ART and } \\
\text { undergoing treatment for TB. Currently on } 8 \text { mg of } \\
\text { BPN. No complaints. }\end{array}$ & $\begin{array}{l}\text { How to continue BPN with } \\
\text { comorbidities such as HIV } \\
\text { and TB? }\end{array}$ & $\begin{array}{l}\text { Continue same medications. Explained about } \\
\text { importance of adherence to OST, ART and } \\
\text { treatment of TB. Importance of brief counsel- } \\
\text { ling sessions in such patients was emphasized. } \\
\text { Also. pharmacokinetics of medications. }\end{array}$ \\
\hline 11. & $\begin{array}{l}\text { 35-year-old male with 5-month use of smack } \\
\text { (heroin). Currently, on BPN } 4 \text { mg/day. Complaint of } \\
\text { back pain }\end{array}$ & $\begin{array}{l}\text { How to manage back } \\
\text { pain which looks severe? } \\
\text { Is it due to withdrawal } \\
\text { symptoms? }\end{array}$ & $\begin{array}{l}\text { Continue BPN } 4 \text { mg/day. Explain detailed } \\
\text { physical examination and rule out organi- } \\
\text { city due to isolated complaint of backpain. } \\
\text { Consider referral to an orthopedic }\end{array}$ \\
\hline
\end{tabular}

Abbreviations: ART, antiretroviral treatment; BPN, buprenorphine; BZD, benzodiazepine; MDR TB, multidrug resistant tuberculosis; OST, opioid substitution therapy. 


\section{Conclusion}

A CVC, one of many digitally driven module of PCPP, may form a useful and pragmatic model to train and guide PCDs working in areas with scarcity of services to provide appropriate and comprehensive management for patients with OUDs, although there is a need to evaluate this model on a larger scale with regular follow-up of patients.

\section{Funding}

Primary Care Psychiatry Program of Uttarakhand is funded by the National Health Mission, Uttarakhand.

\section{Conflict of Interest}

None declared.

\section{References}

1 Drugs UNO, Crime. World drug report 2010. Vienna: United Nations Publications; 2010

2 Rao R. The journey of opioid substitution therapy in India: achievements and challenges. Indian J Psychiatry 2017;59(1):39-45

3 Manjunatha N, Kumar CN, Math SB, Thirthalli J. Designing and implementing an innovative digitally driven primary care psychiatry program in India. Indian J Psychiatry 2018; 60(2):236-244
4 Kulkarni K, Adarsha AM, Parthasarathy R, et al. Concurrent validity and interrater reliability of the "clinical schedules for primary care psychiatry" J Neurosci Rural Pract 2019; 10(3):483-488

5 Manjunatha N, Naveen Kumar C, Suresh B, Jagadisha T, Clinical schedules for primary care psychiatry-version 2.2. In: Manjunatha N, Kumar CN, Math SB, Basvaraju V, Shashidhara HN, Parthasarathy P, eds. Karnataka Telemedicine, Mentoring and Monitoring Program: An implementation Manual of Primary Care Psychiatry, Published by Department of Psychiatry, National Institute of mental Health and Neurosciences, Bengaluru, NIMHANS Publication No. 157,; 2019 (ISBN: 978-81-86506-00-4)

6 Addiction CUNCo, Abuse S. The National Center on Addiction and Substance Abuse at Columbia University. Annual Report: National Center on Addiction and Substance Abuse at Columbia University. Available at: https://www.centeronaddiction.org/ sites/default/files/files/2012-annual-report.pdf

7 Korownyk C, Perry D, Ton J, et al. Opioid use disorder in primary care: PEER umbrella systematic review of systematic reviews. Can Fam Physician 2019;65(5):e194-e206

8 Logan DE, Lavoie AM, Zwick WR, Kunz K, Bumgardner MA, Molina Y. Integrating addiction medicine into rural primary care: strategies and initial outcomes. J Consult Clin Psychol 2019;87(10):952-961 